\title{
PENGUKURAN EFEKTIVITAS MESIN DENGAN MENGGUNAKAN METODE OVERALL EQUIPMENT EFFECTIVENESS (OEE) DAN OVERALL RESOURCE EFFECTIVENESS (ORE) PADA MESIN PL1250 DI PT XZY
}

\author{
Muthi Maitsa Zulfatri ${ }^{1}$, Judi Alhilman ${ }^{1}$, Fransiskus Tatas Dwi Atmaji ${ }^{1}$ \\ ${ }^{1} \mathrm{~S} 1$ Teknik Industri, Fakultas Rekayasa Industri, Universitas Telkom \\ Jl. Telekomunikasi Terusan Buah Batu, Bandung, 40257 \\ *Email : muthimaitsa@gmail.com
}

\begin{abstract}
ABSTRAK
Mesin PL1250 merupakan salah satu mesin yang digunakan dalam pembuatan cover on-off di PT XYZ yang mengalami frekuensi kerusakan terbanyak. Kerusakan mesin menyebabkan terjadinya downtime. Downtime mengakibatkan proses produksi terhenti karena mesin tidak dapat beroperasi. Hal ini menyebabkan penurunan produktivitas karena mesin tidak dapat menghasilkan produk dengan maksimal. Berdasarkan permasalahan tersebut, maka evaluasi terhadap kinerja mesin dilakukan pada mesin PL1250 dengan menggunakan metode Overall Equipment Effectiveness (OEE) dan Overall Resource Effectiveness (ORE). Tujuan dari evaluasi kinerja mesin yaitu untuk mengetahui efektivitas penggunaan mesin dan ketersediaan sumber daya, serta mengetahui kerugian yang muncul selama proses produksi berlangsung berdasarkan six big losses. Hasil penelitian menunjukkan bahwa rata-rata nilai OEE sebesar $76.54 \%$ dan nilai ORE sebesar $73.53 \%$ yang berada di bawah standar global yaitu $85 \%$. Rendahnya efektivitas mesin dipengaruhi oleh dua losses yang paling dominan yaitu reduced speed loss dengan persentase sebesar $36.27 \%$ dan idling and minor stoppages loss dengan persentase sebesar $29.54 \%$. Penyebab rendahnya efektivitas dipengaruhi oleh aspek manusia, mesin, material, dan metode.
\end{abstract}

Kata kunci: Overall Equipment Effectiveness, Overall Resource Effectiveness, Six Big Losses

\begin{abstract}
PL1250 machine is one of the machines used in the manufacture of cover on-off in PT XYZ that has the highest frequency of damage. Machine damage causes downtime. Downtime causes the production process being stopped because the machine could not operate. This leads to a decrease in productivity because the machine cannot produce the product to the fullest. Based on the problem, evaluation of machine performance is done on PL1250 machine using Overall Equipment Effectiveness (OEE) and Overall Resource Effectiveness (ORE) method. The purpose of the machine performance evaluation is to determine the effectiveness of machine use and resource availability, as well as to know the losses arising during the production process is based on six big losses. The results showed that the average OEE value was $76.54 \%$ and the ORE value was $73.53 \%$ which was under the global standard of $85 \%$. The low effectiveness of the machine is influenced by the two most dominant losses, that are reduced speed loss with a percentage of $36.27 \%$ and idling and minor stoppages loss with a percentage of $29.54 \%$. The cause of low effectiveness is influenced by human, machinery, materials, and methods.
\end{abstract}

Keywords: Overall Equipment Effectiveness, Overall Resource Effectiveness, Six Big Losses 


\section{PENDAhUluan}

Perkembangan kompetisi dalam sektor industri saat ini membuat perusahaan dituntut untuk mampu memenuhi permintaan pasar. Kemampuan perusahaan dalam menyediakan atau memproduksi barang mengharuskan perusahaan untuk memiliki produktivitas yang tinggi. Tujuan dari produktivitas yang tinggi adalah untuk menghasilkan produk sesuai kebutuhan dengan memanfaatkan sumber daya dalam produksi baik itu mesin, tenaga kerja, dan material secara efektif dan efisien.

PT XYZ merupakan perusahaan yang bergerak dibidang industri produk pertahanan dan keamanan serta produk komersial. PT XYZ menghasilkan beragam produk komersial, salah satunya yaitu cover on-off yang merupakan bagian dari air brake system. Proses pemesinan cover on-off terdiri atas proses bubut, bor, dan frais. Selama proses produksi yang telah berlangsung, PT XYZ memiliki kendala yaitu terjadi kerusakan mesin yang menyebabkan proses produksi terhambat karena mesin tidak dapat beroperasi. Mesin PL1250 memiliki total kerusakan terbanyak dari pada mesin lainnya yaitu sebanyak 22 kerusakan selama tahun 2017-2018. Adapun total downtime pada mesin PL1250 adalah sebagai berikut.

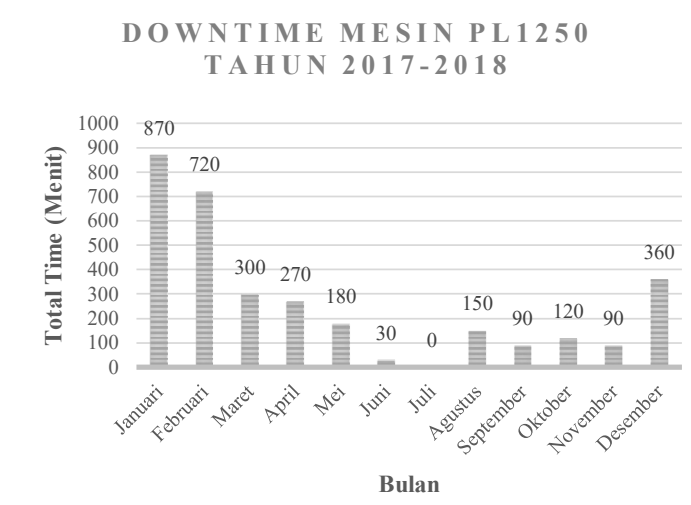

Gambar 1. Data Downtime Mesin PL1250 2017-2018

Proses kerja yang dilakukan pada mesin PL1250 adalah proses bubut. Proses bubut merupakan tahap pertama dalam proses pemesinan cover on-off. Kerusakan mesin ini menyebabkan terjadinya downtime. Downtime merupakan waktu ketika mesin tidak dapat beroperasi dalam jangka waktu tertentu. Downtime yang terjadi mengakibatkan proses produksi pada mesin terhenti sehingga dapat mempengaruhi proses kerja selanjutnya. Selain itu, downtime juga dapat menyebabkan kerugian waktu produksi karena terjadi penurunan kecepatan produksi sehingga mesin tidak dapat menghasilkan produk secara maksimal. Berdasarkan permasalahan tersebut, maka evaluasi efektivitas mesin dilakukan pada mesin PL1250 untuk mengukur kinerjanya. Pengukuran efektivitas mesin dilakukan dengan menggunakan metode Overall Equipment Effectiveness (OEE). OEE merupakan metode pengukuran kinerja mesin atau peralatan dalam proses produksi guna meningkatkan produktivitas (Nayak, Naidu, Shankar, dan Manager, 2013). Selain mesin, sumberdaya yang digunakan turut berperan penting dalam efektivitas mesin. Overall resource effectiveness (ORE) merupakan sistem pengukuran kinerja manufaktur yang telah dikembangkan dengan tujuan memberikan evaluasi yang lebih mendalam daripada OEE dengan mempertimbangkan sumber daya yang meliputi ketersediaan manusia, mesin, material, dan metode (Eswaramurthi dan Mohanram, 2013). Penelitian ini bertujuan untuk mengukur efektivitas mesin dengan menggunakan metode OEE dan ORE, serta six big losses untuk mengetahui kerugian-kerugian yang mempengaruhi rendahnya efektivitas mesin yang nantinya akan dianalisis lebih lanjut dengan menggunakan diagram sebab-akibat untuk mengetahui penyebab penurunan kinerja mesin.

\section{TINJAUAN PUSTAKA}

\section{Overall Equipment Effectiveness (OEE)}

OEE adalah metode yang digunakan untuk mengukur efektivitas dari mesin ataupun peralatan. OEE didefinisikan sebagai ukuran kinerja peralatan total, yaitu sejauh mana peralatan melakukan apa yang seharusnya dilakukan (Olivella dan Gregorio, 2015). Tujuan akhir OEE adalah untuk memaksimalkan efektivitas peralatan (Alhilman, Atmaji, dan Athari, 2017). OEE diusulkan sebagai salah satu cara untuk mengukur kerugian akibat gangguan produksi dengan mengeliminasi six big losses atau enam kerugian besar yang menjadi penyebab kegagalan operasi dari suatu mesin atau peralatan. Beberapa penelitian telah dilakukan untuk menerapkan elemen OEE dan penerapan 
OEE untuk evaluasi kinerja peralatan. Bokrantz et al. (2016) melakukan penelitian dengan menggunakan penilaian OEE dalam mengidentifikasi potensi peningkatan perawatan. Garza-Reyes et al. (2010) menggunakan OEE dalam mengukur kinerja lini produksi dengan melakukan simulasi pada proses bottling bir pada salah satu jalur pembotolan. Hasil penelitian oleh Garza-Reyes et al. (2010) menunjukkan bahwa OEE dapat digunakan dalam proses dengan volume tinggi yang mana pemanfaatan kapasitas merupakan prioritas tinggi dan gangguan dapat menyebabkan pengeluaran biaya dan menyebabkan kerugian kapasitas yang tinggi.

OEE dapat digunakan untuk membantu fokus pada peningkatan kinerja permesinan dan proses terkait dengan mengidentifikasi peluang kinerja yang akan memiliki dampak terbesar pada permasalahan (Rajbir S. dan Singh, 2015). Wudhikarn (2016) menggunakan OEE dalam menentukan peringkat mesin yang bermasalah yang bertujuan untuk memprioritaskan mesin untuk perbaikan pada pabrik pembuatan plafon semen fiber. Saleem et al. (2017) menggunakan penilaian OEE dalam mengukur produktivitas yang mana OEE digunakan untuk menyorot area potensial yang mengalami gangguan dikarenakan adanya kegagalan yang berulang. OEE terdiri atas tiga faktor yaitu availability rate, performance rate, dan quality rate.

Availability rate merupakan total waktu ketika sistem tidak dapat beroperasi dikarenakan adanya pemberhentian.

Availability rate $(A)=\frac{\text { Loading time }- \text { Downtime }}{\text { Loading time }}$

Performance efficiency mengukur total waktu yang digunakan operator secara efisien, yaitu perbandingan antara waktu produksi aktual dengan waktu yang produksi yang diharapkan.

Performance efficiency $(P)=\frac{\text { Ideal cycle time } x \text { output }}{\text { operating time }}$

Quality rate merupakan rasio antara produk yang diterima dengan produk yang dihasilkan. Quality rate $(Q)=\frac{\text { Input }- \text { Volume of qualitydefects }}{\text { Input }}$

\section{Overall Resource Effectiveness (ORE)}

Efektivitas produksi pabrik bergantung pada efektivitas dari peralatan, material, manusia, dan metode yang digunakan. ORE mengukur sistem kinerja manufaktur yang telah dikembangkan dengan tujuan memberikan evaluasi yang lebih mendalam daripada OEE mengenai kinerja mesin berdasarkan aspek manusia, material, mesin, dan metode (Eswaramurthi dan Mohanram, 2013). ORE mengukur tingkat efektivitas dengan menggunakan semua sumber daya, peralatan, operator, teknisi, manajemen lantai produksi, dan sistem pendukung perusahan itu sendiri (Plaza, North, dan Nj, 2001). Pengukuran ORE terdiri atas tujuh faktor yaitu readiness, availability of facility, changeover efficiency, availability of material, availability of manpower, performance efficiency, dan quality rate (Eswaramurthi dan Mohanram, 2013).

Readiness yaitu total waktu ketika sistem tidak siap untuk beroperasi yang disebabkan oleh adanya persiapan atau kegiatan terencana.

Readiness $(R)=\frac{\text { Planned production time }}{\text { Total time }}$

Availability of facility mengukur waktu total ketika sistem tidak beroperasi yang disebabkan oleh breakdown dari fasilitas.

Availability of facility $(A f)=\frac{\text { Loading time }}{\text { Planned production time }}$

Changover efficiency merupakan total waktu ketika sistem tidak beroperasi disebabkan oleh set up and adjustment.

Changover Efficiency $(C)=\frac{\text { operation time }}{\text { Loading ime }}$

Availability of material mengukur total waktu ketika sistem tidak beroperasi dikarenakan tidak tersedianya material.

Availability of material $(A m)=\frac{\text { Running time }}{\text { Operation ime }}$

Availability of manpower menunjukkan total waktu ketika sistem tidak beroperasi dikarenakan ketidakhadiran dari tenaga kerja.

Availability of manpower $(A m p)=\frac{\text { Actual running time }}{\text { Running time }}$

Performance efficiency mengukur total waktu yang digunakan operator secara efisien, yaitu perbandingan antara waktu produksi aktual dengan waktu yang produksi yang diharapkan. Quality rate merupakan rasio antara produk yang diterima dengan produk yang dihasilkan. 


\section{Six Big Losses}

Six big losses merupakan penyebab paling umum dari hilangnya produktivitas berbasis peralatan di bidang manufaktur (Wibowo, Atmaji, dan Budiasih, 2018). Six big losses digunakan untuk mengidentifikasi kerugian yang terkait dengan peralatan untuk tujuan meningkatkan total kinerja dan keandalan aset (Mansur, Rayendra, dan Mastur, 2016). Berikut merupakan faktor-faktor dari six big losses.

a Equipment failures yaitu kerugian ketika peralatan mengalami kerusakan.

b Setup and adjustment yaitu kerugian yang disebabkan karena kegiatan pengaturan dan penyesuaian.

c Idling and minor stoppages yaitu kerugian yang disebabkan karena adanya pemberhentian sementara atau ketika mesin menganggur.

d Reduced speed yaitu kerugian disebabkan oleh penurunan kecepatan operasi.

e Reduced yield yaitu kerugian yang disebabkan oleh cacat pada awal waktu produksi hingga mencapai keadaan yang stabil.

f Quality defect and rework yaitu kerugian yang disebabkan oleh produk cacat atau pengerjaan ulang produk.

\section{METODE PENELITIAN}

Penelitian ini menggunakan dua jenis data yaitu data kualitatif dan data kuantitatif. Data kualitatif digunakan untuk mendapatkan informasi terkait penyebab terjadinya penurunan efektivitas mesin. Sedangkan data kuantitatif digunakan dalam perhitungan efektivitas mesin. Data yang digunakan dalam penelitian ini yaitu data jam tersedia, planned downtime, breakdown, setup and adjustment time, manpower absence time, material shortages, total produksi, dan produk rework.

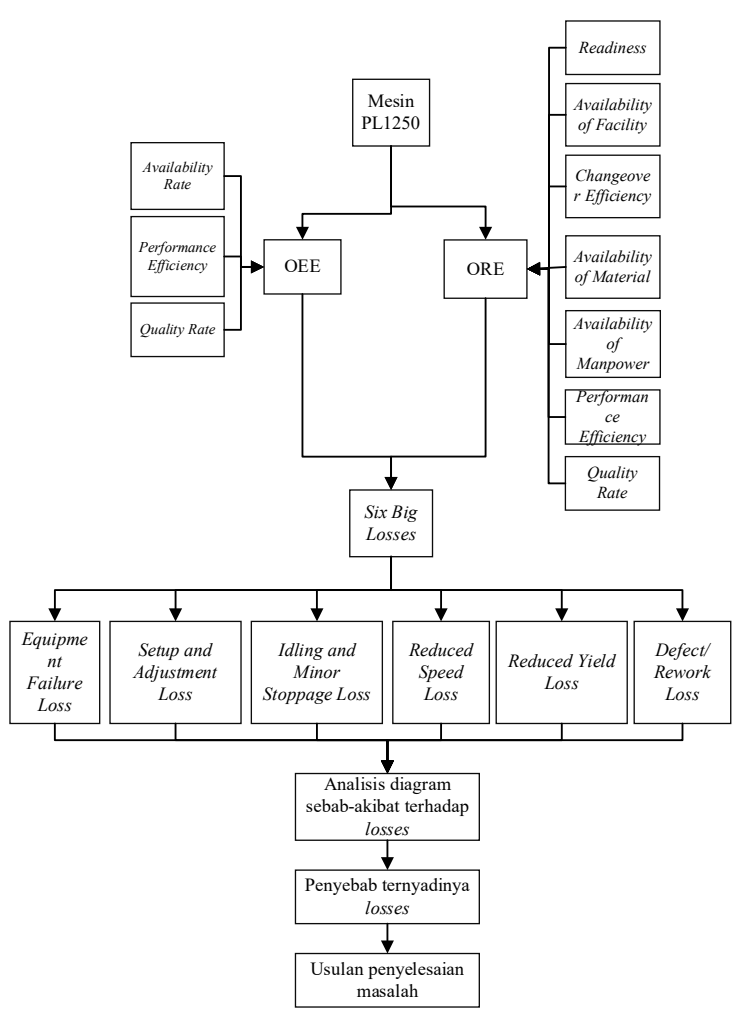

Gambar 2. Model Konseptual

Penelitian ini diawali dengan pengukuran tingkat efektivitas mesin dengan menggunakan metode OEE. OEE mengevaluasi tiga komponen utamanya yaitu availability rate, performance efficiency, dan quality rate. Selanjutnya ketiga komponen OEE tersebut dikalikan untuk mendapatkan nilai OEE.

Perhitungan efektivitas selanjutnya dilakukan dengan menggunakan metode Overall Resources Effectiveness (ORE). Pengukuran ORE terdiri atas tujuh faktor yaitu readiness, availability of facility, changeover efficiency, availability of material, availability of manpower, performance efficiency, dan quality rate. Selanjutnya yaitu mengukur nilai ORE dengan mengalikan seluruh faktor-faktor tersebut.

Setelah mendapatkan nilai efektivitas mesin, langkah selanjutnya yaitu menentukan kerugian berdasarkan six big losses yaitu equipment failures, set-up and adjustment, idling and minor stoppages, reduce dspeed losses, reduced yield, dan quality defect and re-work. Perhitungan six big losses digunakan untuk menentukan kerugian yang paling dominan dalam mempengaruhi penurunan efektivitas mesin. Jenis kerugian yang paling 
dominan selanjutnya dipilih untuk diidentifikasi dengan menggunakan diagram sebab-akibat untuk mengetahui penyebab terjadinya penurunan efektivitas mesin dengan mempertimbangkan empat aspek yaitu manusia, material, mesin, dan metode dan dilanjurkan dengan memberikan usulan terhadap permasalahan yang tersebut.

\section{HASIL DAN PEMBAHASAN Perhitungan OEE}

OEE mengalikan tiga faktornya yaitu availability rate, performance efficiency, dan quality rate.

Tabel 1. Perhitungan OEE Mesin PL1250 Tahun 2018

\begin{tabular}{lcccc}
\hline \multicolumn{1}{c}{ Bulan } & A & P & Q & OEE \\
\hline Januari & $93.34 \%$ & $86.03 \%$ & $95.00 \%$ & $76.28 \%$ \\
Februari & $93.28 \%$ & $92.14 \%$ & $93.44 \%$ & $80.31 \%$ \\
Maret & $87.21 \%$ & $87.71 \%$ & $93.65 \%$ & $71.64 \%$ \\
April & $92.26 \%$ & $90.66 \%$ & $95.20 \%$ & $79.63 \%$ \\
Mei & $88.26 \%$ & $84.91 \%$ & $94.64 \%$ & $70.93 \%$ \\
Juni & $94.17 \%$ & $89.82 \%$ & $92.68 \%$ & $78.40 \%$ \\
Juli & $91.38 \%$ & $90.14 \%$ & $95.56 \%$ & $78.71 \%$ \\
Agustus & $90.28 \%$ & $92.99 \%$ & $93.94 \%$ & $78.87 \%$ \\
September & $93.74 \%$ & $88.51 \%$ & $94.35 \%$ & $78.29 \%$ \\
Oktober & $88.80 \%$ & $82.87 \%$ & $95.04 \%$ & $69.93 \%$ \\
November & $88.34 \%$ & $85.35 \%$ & $96.77 \%$ & $72.97 \%$ \\
Desember & $91.08 \%$ & $94.73 \%$ & $95.69 \%$ & $82.56 \%$
\end{tabular}

Berdasarkan hasil pengolahan data, didapatkan bahwa nilai rata-rata ORE pada tahun 2018 sebesar $73.53 \%$ yang masih berada di bawah standar global yaitu $85 \%$. Hal ini dipengaruhi oleh nilai performance efficiency dan quality rate yang masih berada di bawah standar yang ditetapkan.

Tabel 2. Nilai rata-rata OEE Mesin PL1250 Tahun 2018

\begin{tabular}{lcc}
\hline \multicolumn{1}{c}{ Faktor OEE } & Hasil & $\begin{array}{c}\text { Standar } \\
\text { JIPM }\end{array}$ \\
\hline Availability Rate & $91.01 \%$ & $90 \%$ \\
\hline $\begin{array}{l}\text { Performance } \\
\text { Efficiency }\end{array}$ & $88.82 \%$ & $95 \%$ \\
\hline Quality Rate & $94.66 \%$ & $99 \%$ \\
\hline OEE & $76.54 \%$ & $85 \%$ \\
\hline
\end{tabular}

\section{Perhitungan ORE}

ORE mengalikan tujuh faktornya yaitu readiness, availability of facility, changeover efficiency, availability of material, availability of manpower, performance efficiency, dan quality rate.

Tabel 3. Nilai rata-rata OEE Mesin PL1250 Tahun 2018

\begin{tabular}{lcccccccc}
\multicolumn{1}{c}{ Bulan } & $\mathbf{R}$ & $\mathbf{A r}$ & $\mathbf{C}$ & $\mathbf{A m}$ & $\mathbf{A m p}$ & $\mathbf{P}$ & $\mathbf{Q}$ & $\mathbf{0 R E}$ \\
\hline Januari & $96.07 \%$ & $99.07 \%$ & $95.56 \%$ & $99.90 \%$ & $98.69 \%$ & $86.03 \%$ & $95.00 \%$ & $73.29 \%$ \\
Februari & $96.05 \%$ & $100 \%$ & $94.52 \%$ & $100 \%$ & $98.69 \%$ & $92.14 \%$ & $93.44 \%$ & $77.14 \%$ \\
Maret & $96.27 \%$ & $98.82 \%$ & $94.97 \%$ & $100 \%$ & $92.93 \%$ & $87.71 \%$ & $93.65 \%$ & $68.96 \%$ \\
April & $96.07 \%$ & $99.44 \%$ & $94.02 \%$ & $100 \%$ & $98.67 \%$ & $90.66 \%$ & $95.20 \%$ & $76.50 \%$ \\
Mei & $96.07 \%$ & $98.88 \%$ & $93.52 \%$ & $100 \%$ & $95.44 \%$ & $84.91 \%$ & $94.64 \%$ & $68.14 \%$ \\
Juni & $95.88 \%$ & $100 \%$ & $95.42 \%$ & $100 \%$ & $98.70 \%$ & $89.82 \%$ & $92.68 \%$ & $75.16 \%$ \\
Juli & $95.78 \%$ & $100 \%$ & $95.34 \%$ & $100 \%$ & $95.85 \%$ & $90.14 \%$ & $95.56 \%$ & $75.39 \%$ \\
Agustus & $96.26 \%$ & $99.12 \%$ & $95.37 \%$ & $99.81 \%$ & $95.69 \%$ & $92.99 \%$ & $93.94 \%$ & $75.92 \%$ \\
September & $96 \%$ & $99.44 \%$ & $95.51 \%$ & $100 \%$ & $98.70 \%$ & $88.51 \%$ & $94.35 \%$ & $75.21 \%$ \\
Oktober & $96.10 \%$ & $99.66 \%$ & $95.76 \%$ & $100 \%$ & $93.04 \%$ & $82.87 \%$ & $95.04 \%$ & $67.21 \%$ \\
November & $96.10 \%$ & $99.66 \%$ & $95.31 \%$ & $100 \%$ & $93.01 \%$ & $85.35 \%$ & $96.77 \%$ & $70.13 \%$ \\
Desember & $96.03 \%$ & $100 \%$ & $95.63 \%$ & $100 \%$ & $95.25 \%$ & $94.73 \%$ & $95.69 \%$ & $79.29 \%$
\end{tabular}

Berdasarkan hasil pengolahan data, didapatkan bahwa nilai rata-rata ORE pada tahun 2018 adalah sebesar $73.53 \%$ yang masih berada di bawah standar yaitu $85 \%$. Hal ini dipengaruhi oleh nilai performance efficiency dan quality rate yang masih berada di bawah standar yang ditetapkan.

Tabel 4. Nilai rata-rata OEE Mesin PL1250 Tahun 2018

\begin{tabular}{lcc}
\hline \multicolumn{1}{c}{ Faktor ORE } & Hasil & $\begin{array}{c}\text { Standar } \\
\text { ORE }\end{array}$ \\
\hline Readiness & $96.09 \%$ & $90 \%$ \\
\hline Availability of Facility & $99.51 \%$ & $90 \%$ \\
\hline Changeover Efficiency & $95.08 \%$ & $90 \%$ \\
\hline Availability of Material & $99.94 \%$ & $90 \%$ \\
\hline $\begin{array}{l}\text { Availability of } \\
\text { Manpower }\end{array}$ & $96.22 \%$ & $90 \%$ \\
\hline $\begin{array}{l}\text { Performance } \\
\text { Efficiency }\end{array}$ & $88.56 \%$ & $95 \%$ \\
\hline Quality Rate & $93.20 \%$ & $99 \%$ \\
\hline ORE & $73.53 \%$ & $85 \%$ \\
\hline
\end{tabular}

\section{Perbandingan Metode OEE dan ORE}

Pengukuran efektivitas mesin yang dilakukan pada penelitian ini adalah dengan menggunakan metode OEE dan ORE. Hasil pengolahan data menunjukkan bahwa nilai OEE lebih tinggi daripada nilai ORE. 


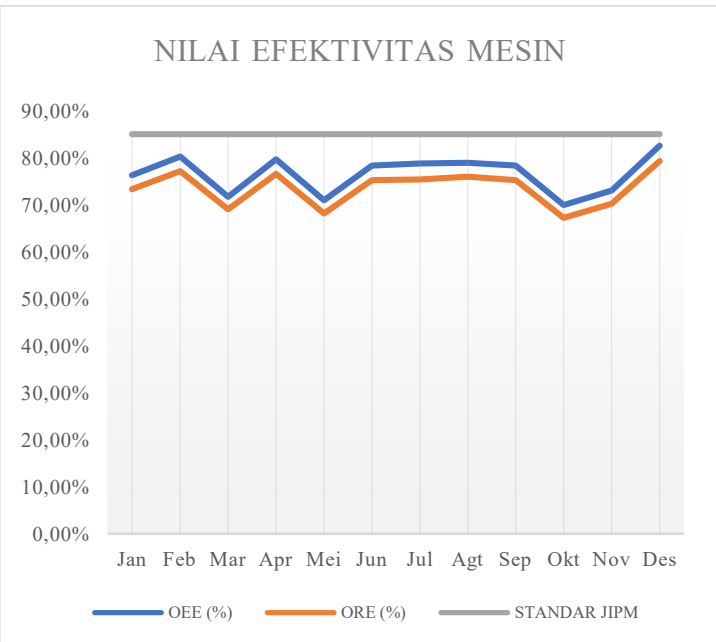

Gambar 3. Grafik Perbandingan OEE dan ORE

Rendahnya nilai ORE ini dikarenakan perhitungan ORE yang lebih rinci daripada OEE. OEE melakukan evaluasi terhadap tiga faktor yaitu availability, performance efficiency, dan quality rate. Sedangkan ORE mengevaluasi tujuh faktor yaitu readiness, availability of facility, changeover efficiency, availability of material, availability of manpower, performance efficiency, dan quality rate. Perbedaan kedua metode ini terletak pada faktor availability. ORE membagi faktor availability berdasarkan sumber daya (manuasia, material, metode, dan mesin), sehingga faktor availability berkembang secara individu menjadi metrik yang terpisah yaitu readiness, availability of facility, changeover efficiency, availability of material, availability of manpower. Pemisahan metrik ini membuat evaluasi terhadap losses dapat difokuskan sesuai dengan faktor penyebabnya.

\section{Perhitungan Six Big Losses}

Analisis six big losses bertujuan untuk mengetahui losses manakah yang paling dominan dalam mempengaruhi rendahnya efektivitas mesin. Berdasarkan perhitungan total losses pada mesin PL1250 didapatkan bahwa kerugian yang paling dominan disebabkan oleh reduced speed loss dengan persentase sebesar $36.27 \%$ dan idling and minor stoppages loss dengan persentase sebesar $29.54 \%$.

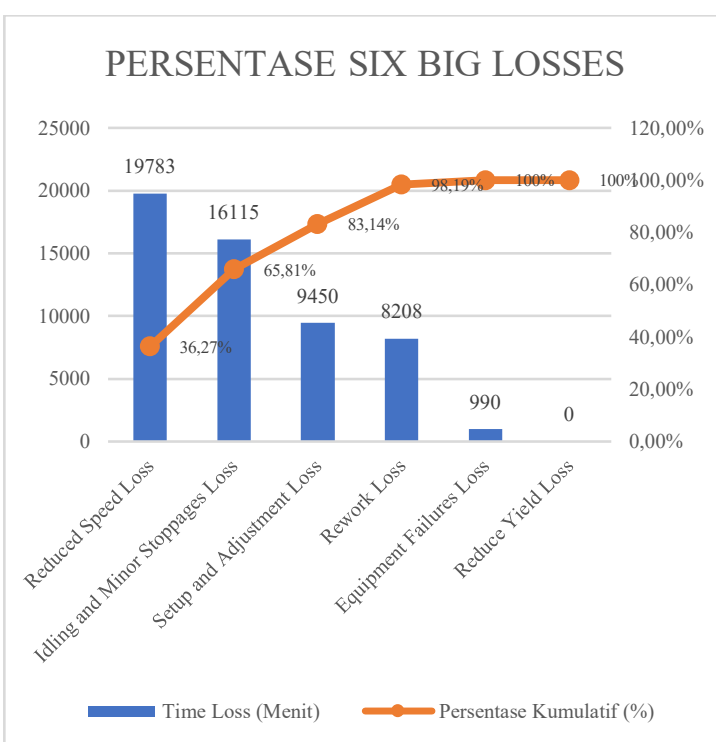

Gambar 4. Persentase Six Big Losses Mesin PL1250 Tahun 2018

\section{Analisis Sebab-Akibat}

Analisis diagram sebab-akibat dilakukan pada losses yang paling dominan yaitu reduced speed losses dan idling and minor stoppages.

a. Analisis sebab-akibat reduced speed loss

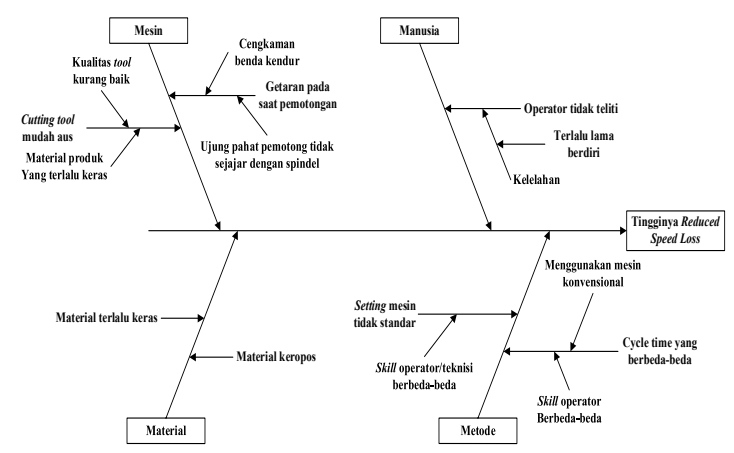

Gambar 5. Diagram Sebab-Akibat Reduced Speed Loss

Faktor yang mempengaruhi reduced speed loss dianalisis berdasarkan empat aspek, yaitu sebagai berikut.

1. Manusia

Operator kurang teliti dalam bekerja dapat disebabkan oleh kelelahan karena operator berdiri terlalu lama sehingga operator kehilangan fokus. Hilangnya fokus operator dapat menyebabkan berkurangnya kecepatan dalam mengoperasikan mesin, sehingga kecepatan operasi dalam satu siklus produk tidak sesuai standar. Proses pengukuran benda kerja masih menggunakan alat bantu, sehingga ketelitian operator sangat dibutuhkan. 
2. Material

Aspek material yang mempengaruhi reduced speed loss yaitu ketika terdapat material keropos dan material produk terlalu keras sehingga susah untuk diproses. Material dari cover on off adalah besi cor sehingga terkadang kekuatan tiap produk berbeda-beda. Jika pada saat proses produksi ditemukan material yang terlalu keras, maka proses pengerjaannya akan lebih lama atau bahkan pengerjaan material tersebut dihentikan dan material tersebut dipisahkan untuk diturunkan kekuatannya. Hal ini juga akan mempengaruhi rework loss.

3. Mesin

Cutting tool mesin yang mudah aus dapat disebabkan oleh dua hal yaitu material produk yang terlalu keras dan kualitas tool yang kurang baik. Material produk yang keras membuat alat pahat menjadi cepat aus karena tidak mampu memotong benda kerja. Sedangkan kualitas tool yang kurang baik dapat menyebabkan alat menjadi lebih cepat terkikis. Selain itu, getaran pada saat pemotongan sering terjadi. Hal ini disebabkan oleh cengkaman benda kerja yang kendur dan ujung pahat potong yang tidak sejajar dengan sumbu spindel.

4. Metode

Ideal cycle time untuk satu produk telah ditentukan oleh perusahaan. Namun, cycle time aktual untuk satu produk itu dapat berbedabeda dikarenakan mesin PL1250 merupakan mesin bubut konvensional, sehingga cycle time aktual produk tidak standar karena proses operasi bergantung pada operator yang mengoperasikan mesin dan skill yang dimiliki tiap operator juga berbeda-beda. Selain itu, dalam hal setting mesin juga tidak memiliki standar sehingga waktu dalam penyetelan mesin tergantung pada operator yang mengerjakannya dan juga keterampilan yang dimiliki oleh operator.
b. Analisis sebab-akibat idling and minor stoppages loss

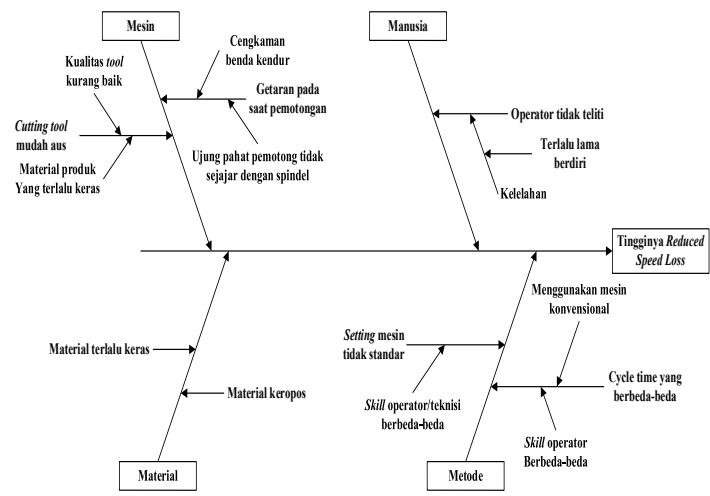

Gambar 6. Diagram Sebab-Akibat Idling and Minor Stoppages Loss

1. Manusia

Setiap mesin terdiri atas satu operator untuk tiap shift. Jika terdapat operator yang tidak dapat hadir dikarenakan izin ataupun sakit, maka mesin tidak beroperasi jika tidak terdapat operator lainnya yang menganggur.

2. Material

Tidak tersedianya material pada saat proses produksi berlangsung dapat disebabkan oleh terganggunya proses sebelum proses pemesinan. Hal ini membuat proses produksi terhenti untuk sementara hingga material tiba.

3. Mesin

Breakdown mesin dapat menyebabkan proses produksi terhenti. Hal ini disebabkan oleh komponen mesin mudah aus karena umur mesin yang juga sudah tua. Selain itu, penyumbatan pada saluran coolant disebabkan oleh residu geram yang tertinggal menyebabkan coolant menjadi mampat dan harus dibersihkan dengan air duster.

4. Metode

Setting mesin tidak standar disebabkan oleh perbedaan keterampilan operator dalam melakukan setting mesin. Selain itu, operator/teknisi tidak mengikuti buku panduan pemeliharaan mesin dan hanya berdasarkan pengetahuan operator/teknisi saja.

\section{Usulan Penyelesaian Masalah}

Setelah mengetahui penyebab masalah dari faktor reduced speed dan idling and minor stoppages dengan menggunakan diagram sebab-akibat, maka dilakukan usulan masalah untuk faktor kedua faktor tersebut yang dapat dilihat pada Tabel 5 dan Tabel 6 . 
Tabel 5. Usulan Penyelesaian Masalah Reduced Speed

\begin{tabular}{|c|c|}
\hline Faktor-Faktor & Penyelesaian Masalah \\
\hline $\begin{array}{ll}\text { Manusia } \\
\text { a. } & \text { Operator } \\
& \text { kurang teliti } \\
\text { b. } & \text { Setting } \\
& \text { tool/benda } \\
& \text { kerja yang } \\
& \text { tidak tepat }\end{array}$ & $\begin{array}{ll}\text { a. Jika operator merasa } \\
\text { Lelah, disarankan } \\
\text { untuk langsung } \\
\text { beristirahat sejenak } \\
\text { untuk memulihkan } \\
\text { kondisi. } \\
\text { b. } \\
\text { Menyediakan area } \\
\text { istirahat yang } \\
\text { nyaman bagi } \\
\text { operator. } \\
\text { c. } & \text { Melakukan setting } \\
& \text { sesuai instruksi dan } \\
\text { tidak teburu-buru. }\end{array}$ \\
\hline \begin{tabular}{ll}
\multicolumn{2}{l}{ Material } \\
a. & Material \\
& Keropos \\
b. & Material \\
& Keras \\
\end{tabular} & $\begin{array}{l}\text { Melakukan } \\
\text { sebelum } \\
\text { memasuki } \\
\text { pemesinan }\end{array}$ \\
\hline $\begin{array}{l}\text { Mesin } \\
\text { a. Tool mudah } \\
\text { aus } \\
\text { b. Getaran } \\
\text { pada saat } \\
\text { pemotongan }\end{array}$ & 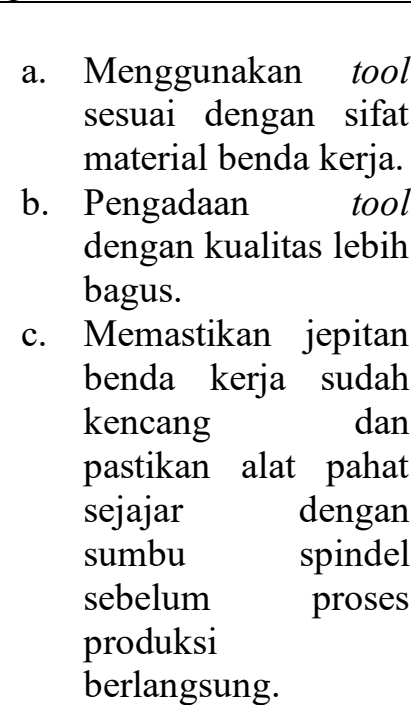 \\
\hline 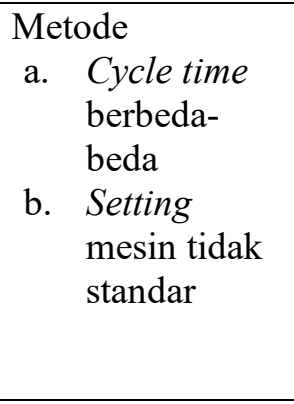 & 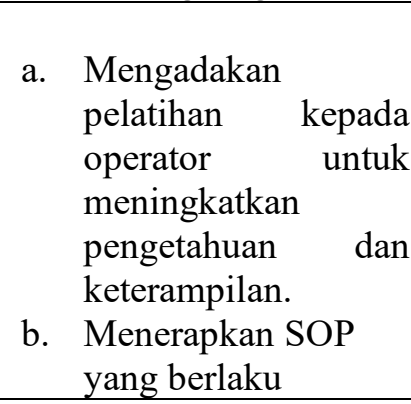 \\
\hline
\end{tabular}

Tabel 6. Usulan Penyelesaian Masalah Idling and Minor Stoppages

\begin{tabular}{|l|l|}
\hline \multicolumn{1}{|c|}{ Faktor-Faktor } & Penyelesaian Masalah \\
\hline Manusia & \\
\hline
\end{tabular}

\begin{tabular}{|c|c|}
\hline $\begin{array}{l}\text { Ketidakhadiran } \\
\text { Operator }\end{array}$ & $\begin{array}{l}\text { Konfirmasi } \\
\text { ketidakhadiran operator } \\
\text { sehari sebelum absen } \\
\text { sehingga dapat dicari } \\
\text { pengganti. }\end{array}$ \\
\hline $\begin{array}{l}\text { Material } \\
\text { Tidak tersedianya } \\
\text { material }\end{array}$ & $\begin{array}{l}\text { Pengadaan dan } \\
\text { pengecekan stok harus } \\
\text { aktual dan terintegrasi } \\
\text { oleh tiap divisi. }\end{array}$ \\
\hline $\begin{array}{ll}\text { Mesin } \\
\text { a. } & \text { Terjadinya } \\
& \text { breakdown } \\
& \text { mesin } \\
\text { b. } & \text { Penyumbatan } \\
\text { pada saluran } \\
\text { coolant }\end{array}$ & 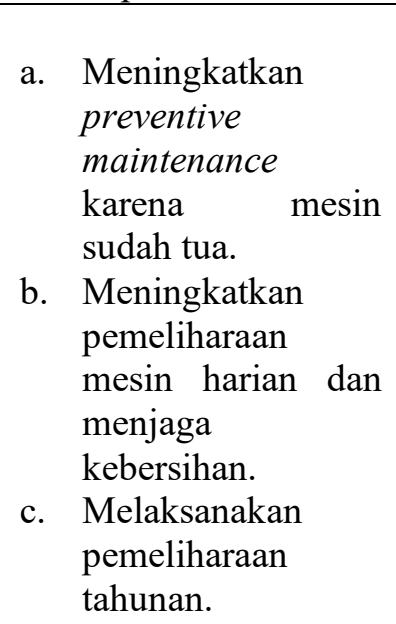 \\
\hline $\begin{array}{l}\text { Metode } \\
\text { Setting mesin tidak } \\
\text { standar }\end{array}$ & $\begin{array}{l}\text { a. Menyediakan SOP } \\
\text { pada workstation } \\
\text { operator } \\
\text { b. Mengadakan } \\
\text { pelatihan kepada } \\
\text { operator untuk } \\
\text { meningkatkan } \\
\text { pengetahuan dan } \\
\text { keterampilan. }\end{array}$ \\
\hline
\end{tabular}

\section{KESIMPULAN}

Berdasarkan hasil penelitian yang telah dilakukan, didapatkan nilai efektivitas dengan menggunakan metode OEE sebesar 76.54\% dan metode ORE sebesar $73.53 \%$. Kedua nilai efektivitas mesin berada di bawah standar global yaitu $85 \%$. Pengukuran kedua metode menunjukkan nilai efektivitas berada di bawah standar sehingga lebih lanjut dilakukan perhitungan six big losses. Hasil perhitungan six big losses menunjukkan reduced speed loss menjadi faktor yang paling dominan dengen persentase sebesar $36.27 \%$ dan diikuti oleh idling and minor stoppages loss dengan persentase sebesar 29.54\%. Kedua losses ini lebih lanjut dianalisis dengan menggunakan diagram sebab-akibat untuk mengetahui penyebab yang mempengaruhi tingginya losses 
tersebut dengan mempertimbangkan aspek manusia, material, mesin, dan metode. Berdasarkan analisis dengan menggunakan diagram sebab-akibat didapatkan penyebab dari reduced speed loss dan idling and minor stoppages loss secara garis besar yaitu, dari segi manusia disebabkan oleh ketidakhadiran operator, ketidaktelitian operator, dan perbedaan skill operator/teknisi. Aspek mesin disebabkan oleh tool yang mudah aus, getaran pada saat pemotongan, penyumbatan pada saluran coolant dan terjadinya breakdown pada mesin dikarenakan umur mesin sudah tua. Aspek material disebabkan oleh keterlambatan material, material keropos, dan material yang terlalu keras. Aspek metode disebabkan oleh cycle time yang berbeda-beda dan setting mesin yang tidak standar.

\section{DAFTAR PUSTAKA}

Alhilman, J., Atmaji, F., \& Athari, N. (2017). Software Application for Maintenance System, 0 (RCM II).

Bokrantz, J., Skoogh, A., Ylipää, T., \& Stahre, J. (2016). Handling of production disturbances in the manufacturing industry. Journal of Manufacturing Technology Management, 27(8), 1054-1075.

https://doi.org/10.1108/JMTM-022016-0023

Eswaramurthi, K. G., \& Mohanram, P. V. (2013). Improvement of Manufacturing Performance Measurement System and Evaluation of Overall Resource Effectiveness, 10(2), 131-138. https://doi.org/10.3844/ajassp.2013.13 1.138

Garza-Reyes, J., Eldridge, S., Barber, K. D., \& Soriano-Meier, H. (2010). Overall equipment effectiveness (OEE) and process capability (PC) measures. International Journal of Quality \& Reliability Management, 27(1), 48-62. https://doi.org/10.1108/026567110110 09308

Mansur, A., Rayendra, R., \& Mastur, M. (2016). Performance Acceleration on Production Machines Using the
Overall Equipment Effectiveness ( OEE ) Approach Performance Acceleration on Production Machines Using the Overall Equipment Effectiveness ( OEE ) Approach.

Nayak, D. M., Naidu, G. S., Shankar, V., \& Manager, A. (2013). Evaluation of Oee in a Continuous Process Industry on an Insulation Line in a Cable Manufacturing Unit. International Journal of Innovative Research in Science, Engineering and Technology, 2(5), 1629-1634.

Olivella, J., \& Gregorio, R. (2015). A case study of an integrated manufacturing performance measurement and meeting system. Journal of Manufacturing Technology Management, 26(4), 515-535.

Plaza, M., North, S., \& Nj, B. (2001). “ Overall Resource Effectiveness" the Key for Cycle Time Reduction \& Capacity Improvements Oded Tal MAX International Engineering Group - Operational Innovation.

Rajbir S., A. J., \& Singh, B. H. (2015). OEE enhancement in SMEs through mobile maintenance: a TPM concept. International Journal of Quality \& Reliability Management. https://doi.org/10.1108/IJQRM-052013-0088

Saleem, F., Nisar, S., Khan, M. A., Khan, S. Z., \& Sheikh, M. A. (2017). Overall equipment effectiveness of tyre curing press: a case study. Journal of Quality in Maintenance Engineering, 23(1), 39-56. https://doi.org/10.1108/JQME-06-20150021

Wibowo, A. P., Atmaji, F., \& Budiasih, E. (2018). Maintenance policy of Jet Dyeing machine using Life Cycle Cost ( LCC ) and Overall Equipment Effectiveness ( OEE ) in PT . XYZ, 2(IcoIESE 2018), 144-147.

Wudhikarn, R. (2016). Implementation of the overall equipment cost loss (OECL) methodology for comparison with overall equipment effectiveness (OEE). Journal of Quality in Maintenance Engineering. 